\title{
Management of Hazardous Waste and Contaminated Land
}

\author{
Hilary Sigman \\ Rutgers University and NBER \\ Sarah Stafford \\ College of William and Mary
}

College of William and Mary

Department of Economics

Working Paper Number 104

October 2010 
COLLEGE OF WILLIAM AND MARY

DEPARTMENT OF ECONOMICS

WORKING PAPER \#104

October 2010

\title{
Management of Hazardous Waste and Contaminated Land
}

Abstract: Regulation of hazardous waste and cleanup of contaminated sites are two major components of modern public policy for environmental protection. We review the literature on these related areas, with emphasis on empirical analyses. Researchers have identified many behavioral responses to regulation of hazardous waste, including changes in the location of economic activity. However, the drivers behind compliance with these costly regulations remain a puzzle, as most research suggests a limited role for conventional enforcement. Increasingly sophisticated research examines the benefits of cleanup of contaminated sites, yet controversy remains about whether the benefits of cleanup in the U.S. exceed its costs. Finally, research focusing on the imposition of legal liability for damages from hazardous waste finds advantages and disadvantages of the U.S. reliance on legal liability to pay for cleanup, as opposed to the government---financed approaches more common in Europe.

\author{
Hilary Sigman \\ Rutgers University and NBER \\ sigman@econ.rutgers.edu
}

Sarah L. Stafford

Department of Economics

College of William and Mary

Williamsburg, VA 23187-8795

slstaf@wm.edu

slstaf@wm.edu 
All economies generate wastes that can be hazardous to human health and the environment. Although the exact definition of a hazardous waste varies across regulatory jurisdiction, hazardous waste generally includes any discarded material that is potentially harmful due to its ignitability, corrosivity, reactivity, or toxicity. Generators of hazardous waste include large industrial plants, such as chemical manufacturers and petroleum refiners, but also smaller facilities, such as small dry cleaners and photo finishers, and even nonprofit and government entities, such as hospitals, universities, and military bases. Given this wide range of sources, the U.S. is estimated to have over 600,000 large and small hazardous waste generators (Stafford 2007b). In 2007, the 16,000 largest U.S. facilities generated 47 million tons of regulated hazardous waste (U.S. EPA 2008). In addition to ongoing hazardous waste generation, many countries have significant land contamination from past hazardous waste disposal and toxic substance use and storage. In the U.S., over a thousand major sites (and many more minor sites) have been or will be subject to cleanup or other responses to address this contamination.

In this review, we first address active hazardous waste management. This research reveals the complexity of behavioral responses even to classic command and control regulations. Regulations provoke responses well beyond their intended targets, for example, affecting the location of economic activity. Research has suggested that traditional enforcement activities only partly explain compliance with regulations and that informal pressures may play an important role. However, the voluntary environmental initiatives that have recently become popular seem to have limited effects on behavior.

In the second section, we discuss cleanup of contaminated sites. An extensive and increasingly sophisticated empirical literature attempts to estimate the harms from contaminated sites and value of cleanup. A few recent studies conclude that cleanup of contaminated sites in the U.S. does not pass a cost-benefit test, but this result remains controversial. 
A third section addresses public policy that ties active waste management and cleanup together: the imposition of legal liability for cleanup costs. This literature again points to complex behavioral responses to public policy: liability for cleanup costs affects not only active waste management and compliance with hazardous waste regulations, but also the cleanup process and real estate markets. In addition, this research highlights the difficulty in aligning incentives with the true social costs of waste management and cleanup.

\section{ACTIVE HAZARDOUS WASTE MANAGEMENT}

Economics research on active waste management has concentrated on understanding behavioral responses to hazardous waste regulations and their enforcement. Unlike cleanup of contaminated land, we know little about the welfare implications of these policies. Distributional concerns, however, have been a focus, as a significant literature has developed on fairness in the location of hazardous waste facilities.

\section{Effect of Hazardous Waste Regulations on Facility Behavior}

In the U.S., the Resource Conservation and Recovery Act (RCRA) regulates generation and management of hazardous waste (Jenkins et al 2009). The RCRA program covers hazardous waste "from the cradle to the grave," i.e., from generation to ultimate disposal, but only applies to active facilities. Much of the waste generated in agriculture and mining would meet the definition of hazardous waste; however, in the U.S. and other countries, waste from these two sectors is regulated separately from other hazardous wastes, as is radioactive waste.

RCRA does not restrict of the quantity of hazardous waste that can be generated. Instead, it imposes standards for management and disposal of wastes and tracking of shipments. Compliance with these standards significantly increased the cost of generating and managing hazardous waste (Sigman, 2000). The most expensive RCRA requirements seem to be the land disposal restrictions, which Congress imposed in the 1984 Hazardous and Solid Waste Amendments (HSWA) to RCRA. The land disposal restrictions require that 
wastes be treated to remove hazardous characteristics (often through incineration) before they may be placed in or on the land. Peretz et al. (1997) report that these restrictions increased the cost of waste management several fold. By estimating the elasticity of demand for waste management to its price, they calculate that the land disposal restrictions reduced waste generation by 47 to 74 percent in Tennessee, pointing to a substantial indirect effect of RCRA on waste generation. ${ }^{1}$

By increasing the cost of legal waste management, RCRA regulations may also encourage substitution of illegal disposal. For example, Sigman (1998b) finds an increase in illegal dumping of waste oil in states that banned land disposal of this waste. Enforcement of hazardous waste regulations is a key determinant of their practical effect. RCRA regulations are enforced primarily through government inspections; unlike programs for other environmental media, facilities are not required to self-report compliance status and third party enforcement (e.g., citizen suits) is limited. With these restrictions, the government's principal tools for securing compliance are the traditional enforcement levers: the probability of inspection and the size of penalties.

To determine the efficacy of penalties, Stafford (2002) studies a dramatic increase in the statutory penalties for RCRA violations. Controlling for the probability of detecting violations, violations decrease after the penalty increase. However, the decrease in violations is small relative to the increase in statutory penalty levels. Studying German counties, Almer \& Goeschl (2010) also find support for a classic deterrence model: the rate of tried offenders and the rate of incarceration both decrease the quantity of illegally disposed waste. However, consistent with Stafford's results for the U.S., they find that

\footnotetext{
${ }^{1}$ Air and water pollution policies may also play a role in hazardous waste generation. In particular, firms might substitute hazardous waste for other pollution if air or water pollution control equipment captures contaminants that must then be managed as waste. However, empirical research also suggests the possibility that releases into different environmental media may be complements as well as substitutes in production. Greenstone (2003) finds that the U.S. Clean Air Act did not increase (and may even have decreased) pollution released into other media. Sigman (1996a) similarly finds a negative effect of state hazardous air pollution regulation on hazardous waste generation, suggesting that the air pollution regulations encouraged firms to substitute away from reliance on the hazardous substances. Thus, air and water pollution controls may have spillover benefits for hazardous waste.
} 
economic, structural, and political factors may influence illegal disposal levels more strongly than deterrence does. Similarly, Hamilton (1996) finds that informal factors, such as environmental group membership in a facility's community, play an important role in securing compliance.

Given the limitations of traditional enforcement, governments have tried to deploy alternative incentives for compliance. Stafford (2003) finds state spending on waste programs and increasing the percentage of employees allocated to regional offices reduce severe violations and state voluntary pollution prevention (P2) programs reduce all types of violations. Sam (2010) examines the effect of P2 adoption by facilities rather than the implementation of $\mathrm{P} 2$ programs by the state and finds that $\mathrm{P} 2$ adoption reduces environmental violations in some industries, but increases violations in others. Practices that involve changes in operating procedures-such as instituting a self-inspection and monitoring program and improving maintenance scheduling or labeling proceduresgenerally result in lower violation rates, whereas practices that involve equipment or material changes do not. However, Evans et al. (2010) find that environmental auditing has no significant long-run impact on compliance.

The limited effectiveness of traditional enforcement tools and the effectiveness of alternative compliance initiatives suggest that standard economic models fail to include important costs and benefits of compliance. Information and transaction costs may be a significant category of excluded costs. RCRA regulations are very complex: many types of materials are regulated and regulatory requirements vary depending on the total amount of waste generated by the facility and how the waste is managed. Although it is difficult to disentangle intentional violations from those that are accidental, Stafford (2006) finds that patterns of violation of U.S. hazardous waste regulations suggest that complexity may be a major source of noncompliance. She also finds that initiatives designed to reduce complexity might help to increase overall compliance. 


\section{Incentive Policies and Voluntary Hazardous Waste Initiatives}

Although U.S. federal regulation of hazardous waste relies heavily on command and control, alternative policy approaches have been proposed and implemented. First, several countries and some U.S. states levy taxes on hazardous waste. In the U.S., state hazardous waste taxes tend to be highest on land disposal with lower rates, or even no tax, on waste that is treated or incinerated. Thus, these taxes might represent a Pigouvian approach; they raise the private costs of waste management to reflect external costs and thus provide incentives to reduce generation, increase recycling, and shift to less harmful forms of waste management. However, neither Sigman (2003) nor Maguire and Jenkins (2009) find evidence that the variation across states reflects variation in the external costs of waste management. Studying hazardous waste taxes levied by the state of New York, Deyle \& Bretschneider (1995) find that higher taxes on land disposal relative to other forms of management reduce the amount of waste sent to landfills and increase other forms of management. ${ }^{2}$

As with regulatory approaches to waste management, hazardous waste taxes raise the costs of legal waste management and may therefore encourage illegal disposal. By contrast, a deposit-refund might accomplish the Pigouvian goal of internalizing external costs of waste management and disposal without these incentives for illegal disposal (Russell 1988). A generalized deposit-refund - an example of the "two-part instruments" analyzed by Fullerton \& Wolverton (2005) - could tax waste precursors and give a refund that varies with the external costs of the waste management method (Dinan 1993, Fullerton \& Kinnaman 1995). For example, it might refund a modest portion of the initial tax for land disposal and a larger share for incineration, if incineration has smaller external costs. Deposit-refunds (with the refund equal to the deposit) are common internationally for end products such as used batteries, electronics, and lubricating oil (Sigman 1995, OECD 2010), but have not been widely used for industrial hazardous wastes.

\footnotetext{
${ }^{2}$ Sigman (1996b) concluded that state hazardous waste taxes reduce waste generation and land disposal, but Gerking (2008) disagrees with her characterization of state taxes in this period and does not replicate her results using his tax data. He concludes the taxes did not affect hazardous waste.
} 
Over the past decade, voluntary environmental initiatives (VEIs) have also gained favor as alternatives to command and control approaches. Under VEIs, firms agree to reduce pollution or implement new processes without a statutory requirement or enforcement threat. Firms may participate in VEIs because they promise public relations benefits or stave off new regulatory requirements or enforcement actions. However, the results of the studies focusing on hazardous waste echo the results of the larger VEI literature: there is very little evidence that VEIs have consistent or significant effects on firm behavior (Khanna \& Brouhle 2008).

For example, several studies examine whether participation in EPA's Industrial Toxics program - a voluntary P2 program commonly known as "33-50" - affects the level of toxic emissions. Khanna \& Damon (1999) find that toxic releases of 33-50 participants in the chemical industry declined from 1991 to 1993, whereas Vidovic \& Khanna (2007) find that toxic releases of participants in the larger manufacturing industry did not decline from 1991 to 1995 as a consequence of the program. Gamper-Rabindran (2006) also finds that participants do not significantly reduce the level of toxicity-weighted emissions relative to non-participants in most industries. In the industries with overall reductions in emissions by participants, off-site transfers to recyclers increased, which suggests that facilities may change the media of their release, rather than reducing their use of toxic chemicals.

The results for other VEIs are also mixed. Harrington et al. (2010) investigate adoption of voluntary P2 activities (rather than participation in a formal pollution prevention program); they find that $\mathrm{P} 2$ activities have only weak short-term effects on toxic emissions and only operating and procedural changes have a significant negative impact on toxic emissions. However, Anton et al. (2004) find that adoption of environmental management systems decreases toxic releases.

\section{Effects of Regulation on the Location of Activity}

Hazardous waste regulation may induce changes in the location of economic activity. In particular, jurisdictions with less stringent regulation or enforcement might attract 
economic activity - the "pollution havens" effect. Studies have looked for evidence of a pollution havens effect in the location decisions of new plants and in the directions of trade both in all goods and in waste alone.

A number of papers consider the effect of variations in general environmental stringency on the location decision of plants (Bartik 1988, Levinson 1996, Fredriksson et al. 2003, Millimet \& List 2004). In the only study to focus specifically on the location of hazardous waste management facilities, Stafford (2000) uses a range of qualitative and quantitative measures of regulations and finds that spending on environmental programs, hazardous waste disposal taxes, and the number of environmentalists in a state deter treatment storage and disposal facilities (TSDs) from locating in that state, but that the stringency of environmental regulations is positively related to the likelihood that TSDs locate in a state.

Studies of international trade similarly suggest that the location of economic activity responds to variations in stringency. Several recent studies look at general international trade and use measures of overall environmental costs, which include the costs of hazardous waste regulations but do not separate them out. These studies have started to find evidence of the pollution havens effect, at least for highly affected industries (Eskeland \& Harrison 2003, Ederington et al. 2005, Levinson \& Taylor 2008).

Waste differs from other regulated pollutants because the pollution itself may be exported, raising distinct issues for the theory of trade policy (Copeland 1991, Cassing \& Kuhn 2003) and creating the opportunity to focus empirical research on trade in waste itself. In the U.S., Levinson (1999b) examines the effect of state disposal taxes on interstate trade in hazardous waste. Using a panel data set of inter-state waste shipments from 1987 to 1995, he initially finds that higher disposal taxes are correlated with higher levels of waste imports, which could be due either to the endogeneity of the tax rate or omitted state characteristics. Supporting that conclusion, both fixed effects models and equations that address endogeneity in the tax rate find a negative relationship between taxes and imports. Levinson (1999a) and Deyle \& Bretschneider (1995) also find effects of hazardous waste taxes on U.S. interstate trade in hazardous waste. 
Recent research provides at least circumstantial evidence of a pollution havens effect from international trade in hazardous waste. Baggs (2009) examines international trade in hazardous waste from 1994 to 1997, before the implementation of the "Basel Ban" on export of hazardous waste by signatories to the 1992 Basel Convention. He finds that countries with higher incomes and more costly environmental regulations accept less foreign hazardous waste for disposal. However, this effect is outweighed by other factors, such as capital per worker, distance costs, and economies of scale in disposal costs. Examining international waste flow data for 2004, Kellenberg (2010) also finds that developing countries with lenient regulations import a disproportionately large share of the world's waste. His analysis shows significantly less waste traded when both the importing and exporting country have ratified the Basel Convention on hazardous waste trade. Although economists generally argue against restrictions on trade such as those in the Basel Convention, Copeland (1991) shows that they can improve welfare in the presence of illegal disposal of waste because trade restrictions may protect countries from dumping.

The welfare implications of pollution havens depend on the reasons for variations in stringency. If the stringency of controls varies with differences in the underlying social costs and benefits, the pollution havens effect is an efficient response by the market to this variation. However, if jurisdictions behave strategically in setting stringency, the pollution havens effect is both a response to an inefficient distortion and evidence that jurisdictions can gain from such strategic behavior. Strategic determinations on stringency may take the form of a classic "race to the bottom" in which jurisdictions chose inefficiently low stringency to attract economic activity or, as Levinson (2003) notes, as a "race to the top" (or "not in my backyard" (NIMBY) syndrome), in which jurisdictions try to deflect the social costs of managing wastes to other jurisdictions.

Testing empirically for strategic behavior is challenging because of the simultaneity between the actions of a jurisdiction and its competitors, but several studies have attempted to investigate the issue. Levinson (2003) examines a panel data-set of 
hazardous waste tax rates from 1989 to 1995 . He finds that states raise taxes in response to higher taxes from competitors, which is consistent with a race to the top. Examining enforcement rather than taxes, Konisky (2007) also finds evidence of strategic responses to other state's enforcement levels. However, he concludes that his evidence would support both a race to the bottom and a race to the top. Sigman \& Traub (2007) examine a process by which states can voluntarily take control of RCRA enforcement and find that greener states preferentially seek this authority, which is inconsistent with the concern that states seek to undercut federal standards.

\section{Location of Hazardous Waste Facilities}

Facilities that generate or manage hazardous waste have the potential to cause significant damage to the environment and communities that surround them. Kiel and McClain (1995) document a significant reduction in housing prices from the announcement and siting of a new waste incineration facility. Thus, residents and environmental activists may organize and lobby to prevent a facility from locating in a particular area. On the other hand, the facilities that generate and manage hazardous waste span a wide range of industries and are an important source of tax revenues and jobs, so communities may also want to attract these facilities.

Hazardous waste has been a major focus of concern about "environmental equity." In an influential study, United Church of Christ (1987) showed a significant correlation between the number of hazardous waste facilities in a zipcode and the percentage of minorities in that zipcode. Since that initial study, an extensive literature has more rigorously examined the socioeconomic characteristics of residents living close to hazardous waste facilities. Hamilton (2005) and Shadbegian \& Wolverton (2010) provide detailed reviews of this literature; studies differ in the definition of proximity to the facility, the sorts of facilities they study, and other dimensions and come to varied conclusions. For example, Anderton et al. (1994) examine census tracts surrounding commercial TSDs and find no consistent significant differences in the racial or socioeconomic makeup of those tracts compared to tracts with no commercial TSDs. 
The policy implications of any association between hazardous waste facilities and disadvantaged communities depend on whether the socioeconomic characteristics of the community affect the siting decision or vice versa. To try to sort out the causality, a few studies have looked at determinants of new facility siting, with mixed conclusions. Been \& Gupta (1997) find no evidence that the census tracts receiving new TSDs were disproportionately African-American or low-income, although they did have a higher percentage of Hispanics than other census tracts. By contrast, Pastor et al. (2001) look at high-capacity TSDs in Los Angeles and find that minorities in general are disproportionately exposed to these facilities at the time of siting. Wolverton (2009) examines TRI facility locations in Texas using a conditional logit model and finds that racial composition is not a significant determinant of new plant location, although the likelihood that a plant chooses a particular location falls as the income of the community rises. Studies also have mixed conclusions about whether minority shares increase after siting, with some studies finding they do not (Been \& Gupta 1997, Pastor et al. 2001) and others finding they do (Lambert \& Boerner 1997, Wolverton 2009).

If economic factors alone cannot explain any disproportionate effect on minority communities, some other feature of the siting process must be to blame. Hamilton (1993) posits that some communities have less ability to engage in collective action to oppose the facility. Controlling for local capacity usage, demand for waste services, and factors that are likely to affect labor and land costs, Hamilton finds that his proxy for the ability of the community to engage in collective action - voter turnout in the 1980 Presidential election - significantly lowers facilities' likelihood of planning expansion in a community.

When trying to find a place to locate, waste management facilities sometimes offer payments to communities, known as host fees. These fees may help reduce disparity in welfare that arises because some communities must bear the cost of waste management activities. Theoretical research addresses efficient design of such compensation mechanisms (e.g., Kunreuther et al. 1987, Minehart \& Neeman 2002). Ingberman (1995) concludes that these compensation schemes may function poorly in practice once one 
considers geographic issues, such as the potential for transboundary spillovers and costs that vary among voters within the jurisdiction.

\section{CLEANUP OF CONTAMINATED SITES}

Land disposal of hazardous waste and other activities, such as use and storage of toxic substances, have created a legacy of contaminated land. Most developed countries are now engaged in the cleanup of these sites.

In the U.S., the policy for cleanup of abandoned contaminated sites is the Comprehensive Emergency Response Compensation and Liability Act (CERCLA), passed in 1980 in a rushed response to concerns about the contamination in Love Canal, New York. The program became commonly known as Superfund because it created a trust fund for the cleanup of these sites. RCRA also has cleanup provisions, called Corrective Action, which are similar in structure to Superfund and may ultimately become more important as the stock of abandoned sites eligible for Superfund cleanup declines. In addition, all 50 US states have cleanup programs for sites that do not enter the federal Superfund program.

Other countries have similar programs, often of much more recent vintage. Several European countries adopted legislative programs in the 1990s, although common law countries could initiate cleanup under nuisance and negligence actions before legislative programs began.

The desirable extent of cleanup - "how clean is clean?" - is an important question for public policy toward contaminated sites. Many remedies may address contamination. The most expensive remedies involve removing the source of contamination. Contaminated soil may be excavated and incinerated, either on- or off-site. A second type of remedy involves "containment," that is, preventing migration of contaminated material. These remedies include constructing retaining walls and installing cement caps over contaminants. Finally, 
the remedy can just reduce human exposure, for example, by fencing off the site or providing access to city water as an alternative to contaminated groundwater.

\section{Measuring the Benefits of Cleanup}

Choosing the optimal remedy requires estimating the benefits of cleanup, which is both conceptually and methodologically challenging. ${ }^{3}$ Conceptually, the challenge is to conduct welfare analysis when individuals may be poorly informed or have difficulty understanding small risks. Cost-benefit calculations may use existing states of information (and possibly unfounded fears), but this approach risks spending resources on fears that might be much more cheaply addressed through information. Gayer et al. (2002) find that the market valuation of exposure to Superfund sites responds strongly to the release of information about the risk posed by these sites. Alternatively, analysts can use toxicological models that predict harms and apply standard values of risk reduction, especially the value of a statistical life (VSL). Yet, this approach may undervalue the real disutility from uncertain situations and requires transfer of values of risk reduction from other contexts to these contaminated-site risks.

The economics literature has mostly focused on the first approach. In particular, a large number of studies attempt to estimate the market value of perceived risks from contaminated sites using hedonic property value models. U.S. EPA (2009) provides an extensive review of the literature that estimates the effects of contaminated sites on property values and presents a summary table of results. A number of early studies focus on one or a few sites, although more recent studies have begun to show a national picture (Noonan et al. 2007, Kiel \& Williams 2007, Greenstone \& Gallagher 2008; GamperRabindran \& Timmins 2010).

Early studies estimate the effect of proximity to a contaminated site on housing prices and find that houses near these sites have significantly lower prices. However, these price discounts may not capture the benefits of cleanup. Some recent studies find that cleanup

\footnotetext{
${ }^{3}$ Most analysts believe the benefits of clean-up are almost entirely from reduction in risks to human health; benefits to ecosystems are usually considered small. Our discussion thus follows the literature in focusing on human health risk.
} 
does not fully eliminate discounts (McClusky \& Rausser 2003, Messer et al. 2006), although earlier studies conclude that it does (Kohlhase 1991, Dale et al. 1999). Property values may not completely recover because the cleanup remedies do not fully remove risks or because the sites continue to bear some stigma.

In response, recent studies estimate the benefits of cleanup decisions and activities, rather than simple proximity to site. However, this approach raises at least two of its own challenges. First, changes in values may reflect the revelation or dissemination of information about the severity of the risks, rather than real changes in these risks. For example, a property value decline associated with adding a site to the National Priorities List (NPL) - the set of sites eligible for large scale federal cleanups - may indicate that households learn bad news from this action, not that they do not value the prospect of a federal cleanup. Second, real estate market valuations may build in expectations about future activities at the site. Thus, a small appreciation in housing values upon completion of cleanup may indicate that property values already anticipated this event.

Studies that rely on property values must also confront several methodological issues common to hedonic analyses. First, the hedonic price schedule represents the equilibrium of supply and demand and may not capture households' willingness to pay for nonmarginal changes in the condition of a site (Gayer 2000, Greenstone \& Gallagher 2008). Second, estimating the magnitude of the property value effect requires a definition of the affected group. Studies with data on house sale transactions typically focus on houses within a few miles of the site; using a fixed distance is simple, but may miss the subtleties of how local residents come into contact with the site. Other studies use aggregate data on house prices for some administratively-defined geographic unit, such as the census tract; again, these units may not do a good job of representing exposure to the site. Finally, unobserved geographic heterogeneity in housing and community characteristics may bias the estimated effects. Studies have found that socioeconomic characteristics of neighboring communities affect the inclusion of sites in the federal Superfund program and the cleanup decisions at those sites (Viscusi \& Hamilton 1999), so unmeasured attributes of communities may also play a role. 
Several strategies can avoid bias from such unobserved heterogeneity. A repeat-sales approach estimates the value of information revelation or cleanup activities based on the change in prices for houses that resold after the activity (e.g., Mendelsohn et al. 1992, Gayer et al. 2002, Gamper-Rabindran \& Timmins 2010), removing effects of the home and area that do not change over time. Studies also conduct panel data analyses of communities, usually at the census tract level, to control for unchanging attributes of the communities (Noonan et al. 2007, Greenstone and Gallagher 2008).

Greenstone \& Gallagher (2008) develop a novel quasi-experimental research design to address the unobserved heterogeneity problem. Sites are eligible for inclusion on the NPL if they receive a hazard ranking score above an arbitrary threshold. For the earliest candidates for the NPL, this threshold was unknown when the sites were scored. Thus, Greenstone \& Gallagher posit that NPL status is more randomly assigned to this group of sites than other sites and focus on the effect of NPL listing on census tracts with sites in this first set of candidates. They also employ a regression discontinuity approach which focuses on the subset of these census tracts with sites just above and below the threshold; these census tracts should be quite similar except in the very large difference in the cleanup their sites received. Greenstone \& Gallagher find substantially lower estimates of the value of NPL listing with their quasi-experimental designs than with a more standard comparison of housing appreciation in all census tracts with and without NPL sites, supporting concerns about the influence of unobserved heterogeneity on earlier estimates.

Finally, some studies use alternatives to the hedonic approach. Stated preference approaches allow researchers more opportunities to randomize which households determine the valuations and to value multiple cleanup decisions; however, these studies have generally found values of contaminated site cleanup and VSLs similar to those found in the hedonic studies (Chattopadhyay et al. 2005, Alberini et al. 2007). Studies have also looked for non-price responses as evidence that households value changes at these sites; in particular, households with lower tolerance for risk would move in and the housing stock 
increase. Noonan et al. (2007) find that these changes do occur, but Greenstone \& Gallagher (2008) do not find them with their quasi-experimental approach.

\section{Comparing Costs and Benefits of Cleanup}

Valuation of benefits of cleanup should ultimately lead to judgments about the efficiency of contaminated site cleanup. Several recent studies raise concerns that cleanup costs are very high relative to benefits. Hamilton \& Viscusi (1999) use detailed risk assessments by EPA for a sample of 145 Superfund sites to evaluate the cost per cancer case avoided. They find that an avoided cancer case cost \$388 million (in 1993 dollars) at the median site in their study, almost two orders of magnitude above conventional estimates of the value of a statistical life. The variance across sites in cost per avoided cancer case is high. A few sites that pose substantial risk would pass a cost benefit test, if the usual VSL is the value of a cancer case avoided.

Although they use a hedonic approach rather than expert risk assessment, Greenstone \& Gallagher (2008) come to a similarly negative conclusion. Once they apply their quasiexperimental design, they find that final listing of a site on the NPL does not significantly increase housing prices in the site's census tract; they explicitly test for and reject an increase in prices sufficient to cover the average costs of cleanup of an NPL site, which they calculate to average $\$ 43$ million.

Gamper-Rabindran \& Timmins (2010) adapt the Greenstone-Gallagher research design to examine deletion of sites from the NPL (a measure of completion of cleanup) and find significant positive effects of deletion on housing prices in the census tract, which they confirm with a repeat-sales analysis of individual properties. Assessing two individual sites, they find average benefits of about the same magnitude as average costs. They argue that Greenstone \& Gallagher may conflate the effects of negative information with the positive benefits of cleanup. In using measures of progress beyond listing, however, Gamper-Rabindran \& Timmins may re-introduce some endogeneity in the treatment variable that the Greenstone-Gallagher approach is meant to purge. 
Although the hedonic literature allows an overall cost-benefit assessment of cleanup, it has been less useful for trying to improve the efficiency of cleanups by better tailoring costs to benefits at specific sites. Remedies differ greatly across sites, so "cleanup" has many different meanings. Yet, hedonic valuation studies have tended either to focus on a single site or to estimate a uniform benefit of cleanup across all sites nationally, making it difficult to assess the effects of this heterogeneity. Gupta et al. (1999) suggest the EPA does tradeoff costs against the "permanence" of the cleanup remedies it selects, as efficiency requires. However, Viscusi \& Hamilton (1999) conclude that the EPA uses many of the same heuristics in dealing with risk that have been identified in individual behavior, resulting in inefficient choices. As the dispersion in costs per cancer avoided in Hamilton \& Viscusi (1999) suggests, the best chance for improvements in the efficiency of cleanup may lie in reforming this site-by-site decision-making.

\section{PAYING FOR CLEANUP}

Another policy debate concerns the desirability of funding cleanup through legal liability and the form any liability rules should take. Legal liability imposed on the generators and transporters of waste and past and present owners of contaminated land pays for most U.S. Superfund cleanup. Liable parties must either undertake cleanup themselves or reimburse the government for cleanup by paying into a dedicated trust fund, which also received some tax financing in earlier years. Other countries also use liability financing; however, most European countries rely more on government funding of cleanup than the U.S. (for Sweden, see Forslund et al. 2009). Thus, one might ask whether the U.S. or European approach is preferable.

Countries also vary in the liability rules they impose (Clarke 2001). U.S. Superfund liability has three controversial characteristics. First, liability is strict, meaning that parties are liable even if they took due care to avoid contamination. The E.U. debated strict liability preceding the adoption of the 2004 Environmental Liability Directive and settled on a mixed regime in which only certain hazardous activities are subject to strict liability. Second, courts have interpreted Superfund to impose "joint and several" liability, meaning 
that the government may sue any liable party for the entire cost of cleanup at the site, regardless of that party's contribution to the contamination. Most European countries also rely on joint and several environmental liability, but some have begun restricting its use. Third, Superfund liability is retroactive, covering activities that predate the passage of the law in 1980.

To assess the use of liability and of different liability regimes, we consider implications for active waste management, for the cleanup process at the sites, for transaction costs, and for the real estate market.

\section{Incentives for Active Waste Management}

Liability may create desirable incentives for current waste management. Firms that currently manage waste must consider the threat of liability in deciding the type and amount of waste to generate and the nature of their management of these wastes. RCRA tries to strengthen these incentives by imposing "financial responsibility" requirements on active waste management facilities requirements (Boyd 1997): to satisfy these requirements, facilities must show they have the depth of pockets or insurance to cover future liability.

Empirical evidence suggests that liability for cleanup does have an important influence on active management of toxic substances. In the U.S., the states vary in the liability rules they impose (Alberini \& Austin 1999). Researchers have used this variation to study the effects of liability, particularly strict liability, on active waste management. Strict liability can increase precaution if the due care standard under the alternative policy is set lower than the private parties would choose. Using the variation in reliance on strict liability across states, studies have found that strict liability does increase precaution: it reduces accidental spills (Alberini \& Austin 2002), increases compliance with hazardous waste laws (Stafford 2003), and discourages the import of hazardous waste to the state (Alberini \& Frost 2007). These studies are not only relevant to the choice of strict liability, but also demonstrate empirically the relevance of liability for cleanup to decisions about active waste management. 
In addition, several studies find evidence that firms consider future liability in deciding which waste management facility to use. Alberini \& Bartholomew (1999) find that the choice of management facility depend on a facility's compliance history and existing contamination at the site, as well as the cost of shipping to the facility and disposal costs. Generators prefer to ship to wealthier companies, consistent with concern about liability should the management facility go bankrupt. Stafford (2007a) looks at demand for all hazardous waste management services nationwide and also finds that noncompliance decreases demand for a TSD's services in the short run.

However, the incentives that liability creates for increased precaution in active waste management may not improve social welfare for several reasons. First, liability is frequently based on cleanup costs, rather than harms, and thus may not properly internalize the externality. As discussed above, some recent research suggests that cleanups may be more extensive than optimal. If so, the threat of liability for cleanup costs may encourage precaution that is excessive from a social perspective, creating additional costs from inefficient cleanup choices (Polinsky \& Shavell 1994).

In addition, the form of liability may contribute to inefficient incentives. First, joint and several liability can encourage either too much or too little precaution since it can break the link between the harms a polluter causes and the damages it must pay (Kornhauser \& Revesz 1995, Tietenberg 1989). Alberini \& Frost (2007) find that joint and several liability discourages waste imports to a state, which provides empirical evidence that this particular form of liability affects waste management decisions. Second, retroactive liability does not provide direct incentives for current decisions about risk. A large share of the private cost of Superfund is attributable to activities from before the 1980 passage of CERCLA (Probst et al. 1995). Boyd \& Kunruether (1997) argue that such retroactive liability may even weaken incentives for precaution because it raises the likelihood that a liable party becomes judgment proof through insolvency. 


\section{Effect of Liability on Cleanup}

Relying on liability as opposed to public financing also has implications for the nature and speed of site cleanups. Liability helps privatize cleanups because liable parties may dispatch their responsibility by undertaking government-approved cleanups.

Privatization may provide the usual advantages of cost control and information: private parties may have stronger incentives to control cleanup costs, better knowledge of the contamination, and greater ability to limit disruption to current economic activity at the site.

However, the involvement of private parties may also affect the conduct of cleanup in ways that have more ambiguous welfare implications. In an effort to lower their costs, private parties may delay cleanup (Rausser et al. 1998). Sigman (2001) analyzes the speed of three stages of the Superfund process (listing, remedy selection, and cleanup) and finds evidence that liable parties delay the early stages of the process. Sigman (1998a) finds evidence that deep-pocketed liable parties also use their influence to encourage the selection of less extensive cleanup remedies. Whether this influence amounts to desirable cost control or undesirable interference of concentrated private interests depends on the efficiency of cleanup decisions, which, as discussed above, remains controversial.

\section{Transaction Costs}

Liability gives rise to substantial legal costs, as the government sues liable parties and liable parties sue each other and their insurers. Dixon (1995) estimates that as much as $30 \%$ of private spending on Superfund will be transaction costs, based on surveys of liable parties and their insurers. However, public financing would require increases in distortionary taxes and thus might create an excess burden of similar magnitude.

The form of liability may also affect transactions costs. If liability rules encourage out-ofcourt settlement, costs may be much lower than with drawn-out legal battles and trials. In particular, research has shown that joint and several liability can either encourage or discourage settlement, depending on the correlation across defendants in the likely outcome if the case were to go to trial (Kornhauser \& Revesz 1995). Chang \& Sigman 
(2000) examine the effects of joint and several liability on the probability and speed of settlement in Superfund cases and conclude that, in practice, joint and several liability under Superfund does not discourage settlements and may even encourage them.

\section{Brownfields}

Finally, environmental liability may discourage redevelopment of "brownfields" - sites with actual or potential contamination from their past use. Communities seek to redevelop these sites not only as a source of urban blight but also failure to use these sites may result sprawl as relatively pristine land substitutes for old industrial land. Policy-makers are concerned that liability for cleanup is a substantial deterrent to the reuse of these brownfields, since liability may pass from sellers to buyers.

In a basic model with land price adjustments, liability will not deter land sales or redevelopment; land prices will fall enough to compensate buyers for the expected liability. Some additional problem is necessary for liability to deter sales or redevelopment (Boyd et al. 1996). Adverse selection may arise if sellers have private information about the amount of contamination at the site or the obstacles to cleanup (Segerson 1994). Another possible problem is "imperfect detection or enforcement": the government is unaware of contamination or does not require cleanup until the property is sold or slated for redevelopment. With imperfect detection or enforcement, some properties will be left alone because their value once clean does not exceed the cleanup costs. Property sales may also increase private costs if the buyer has deeper pockets than the seller and thus is less likely to be judgment proof (Segerson 1993). Finally, Chang \& Sigman (2007) find that joint and several liability in particular may deter sales. Increasing the number of defendants, as a sale would, increases the government's expected recovery and thus imposes an implicit tax on transactions. Using data on the share of costs the government recovers in Superfund lawsuits, Chang \& Sigman (2010) estimate a substantial magnitude for this implicit tax.

Empirical research has found evidence that liability is capitalized into land prices (Jackson 2002). For example, McGrath (2002) finds that likely contamination reduces site prices in 
Chicago by $\$ 1$ million per acre, fully capitalizing (or even over-capitalizing) cleanup costs. For inefficiency, however, liability must induce a reduction in the quantity of land redeveloped. Land that is more likely to be contaminated is not always less likely to used (Schoenbaum 2002); however, this result may arise from a correlation between historical land use and other characteristics that make the site attractive. To address this unobserved heterogeneity, Sigman (2010) studies a panel of cities and finds higher industrial vacancy rates and reported brownfield acreage when states adopt joint and several liability. These results suggest that liability does indeed deter redevelopment, despite land price adjustments.

In response to the perceived problems with liability, numerous states and the federal government have adopted brownfields policies. These policies provide outright grants, make available "voluntary" cleanup opportunities to resolve liability, and offer various forms of liability protection to new owners. Surveys find that developers in Europe and the U.S. attribute substantial value to liability relief (Alberini et al. 2005, Wernstedt et al. 2006). However, Alberini (2007) finds that the voluntary cleanup program in Colorado had little real effect on redevelopment.

\section{CONCLUSION}

The economics literature addresses many different questions and policy concerns related to hazardous wastes and contaminated land. However, much research is still required, even in the areas where the literature is most extensive. For example, despite extensive research on the benefits of Superfund cleanup, the economics literature has yet to reach consensus on whether cleanup does increase housing values. In addition, the literature on benefits of cleanup tends to assess either single sites or the average value for the entire program. Thus, this literature does not help to tailor remedies for particular sites. Given the great heterogeneity of sites, improvement in site-by-site decisions might be an important source of efficiency improvements. 
Despite its limitations, the literature on welfare analysis has proceeded much further for Superfund than for RCRA. We lack any econometric assessments of the effects of RCRA in reducing risk and have only a few studies of its overall effects on waste generation or economic activity. Although a number of studies have focused on RCRA compliance and participation in voluntary environmental programs, our understanding of the drivers of compliance and the effect of voluntary programs on environmental performance is still quite limited.

Research on all aspects of hazardous waste has focused on the U.S., with only limited empirical analysis in other countries. This focus is partially for convenience: the U.S. began its policies early and offers econometricians the opportunity to compare the effects of varying state policies within consistent national datasets on outcomes. However, lack of research means other countries must evaluate policies in a more uncertain environment. The greatest need for research is on the management of hazardous wastes and contaminated sites in developing countries, where risks to human health may be especially great, but current information is largely anecdotal. 


\section{LITERATURE CITED}

Alberini A. 2007. Determinants and effects on property values of participation in voluntary cleanup programs: The case of Colorado. Contemp. Econ. Policy. 25 : 415-32

Alberini A, Austin D. 2002. Accidents waiting to happen: Liability policy and toxic pollution releases. Rev. Econ. Stat. 84 : 729-41

Alberini A, Austin D. 1999. On and off the liability bandwagon: Explaining state adoptions of strict liability in hazardous waste programs. J. Regul. Econ. 15 : 41-63

Alberini A, Bartholomew J. 1999. The determinants of hazardous waste disposal choice: An empirical analysis of halogenated solvent. Contemp. Econ. Policy. 17 : 309-20

Alberini A, Frost S. 2007. Forcing firms to think about the future: Economic incentives and the fate of hazardous waste. Environ. Resour. Econ. $36: 451-74$

Alberini A, Longo A, Tonin S, Trombetta F, Turvani M. 2005. The role of liability, regulation and economic incentives in brownfield remediation and redevelopment: Evidence from surveys of developers. Reg. Sci. Urban. Econ. 35 : 327-51

Alberini A, Tonin S, Turvani M, Chiabai A. 2007. Paying for permanence: Public preferences for contaminated site cleanup. J. Risk Uncertainty. 34 : 155-78

Almer C, Goeschl T. 2010. The Sopranos redux: The empirical economics of waste crime. SSRN eLibrary.

Anderton DL, Andy B. Anderson, Peter H. Rossi, John Michael Oakes, Michael R. Fraser, et al. 1994. Hazardous waste facilities: 'Environmental equity' issues in metropolitan areas. Eval. Rev. $18: 123-40$

Anton WRQ, Deltas G, Khanna M. 2004. Incentives for environmental self-regulation and implications for environmental performance. J. Environ. Econ. Manage. 48 : 632-54

Baggs J. 2009. International trade in hazardous waste. Rev. Int. Econ. 17 : 1-16

Bartik TJ. 1988. The effects of environmental regulation on business location in the United States. Growth Change. 19 : 22-44

Been V, Gupta F. 1997. Coming to the nuisance or going to the barrios? A longitudinal analysis of environmental justice claims. Ecol. Law Q. 24 : 1 
Boyd J. 1997. 'Green money' in the bank: Firm responses to environmental financial responsibility rules. Manage. Decis. Econ. 18 : 491-506

Boyd J, Harrington W, Macauley MK. 1996. The effects of environmental liability on industrial real estate development. J. Real Estate Financ. 12 : 37-58

Boyd J, Kunreuther H. 1997. Retroactive liability or the public purse? J. Regul. Econ. 11 : 7990

Cassing J, Kuhn T. 2003. Strategic environmental policies when waste products are tradable. Rev. Int. Econ. $11: 495-511$

Chang HF, Sigman H. 2007. The effect of joint and several liability under superfund on brownfields. Int. Rev. Law Econ. 27 : 363-84

Chang HF, Sigman H. 2000. Incentives to settle under joint and several liability: An empirical analysis of Superfund litigation. J. Legal Stud. 29 : 205-36

Chang HF, Sigman HA. 2010. An empirical analysis of cost recovery in Superfund cases: Implications for brownfields and joint and several liability. SSRN eLibrary.

Chattopadhyay S, Braden JB, Patunru A. 2005. Benefits of hazardous waste cleanup: New evidence from survey- and market-based property value approaches. Contemp. Econ. Policy. $23: 357-75$

Clarke C. 2001. Update comparative legal study. European Commission, Brussels, Belgium

Copeland BR. 1991. International trade in waste products in the presence of illegal disposal. J. Environ. Econ. Manage. 20 : 143-62

Dale L, Murdoch JC, Thayer MA, Waddell PA. 1999. Do property values rebound from environmental stigmas? Evidence from Dallas. Land Econ. 75 : 311-26

Deyle RE, Bretschneider SI. 1995. Spillovers of state policy innovations: New York's hazardous waste regulatory initiatives. J. Policy Anal. Manag. 14 : 79-106

Dinan TM. 1993. Economic efficiency effects of alternative policies for reducing waste disposal. J. Environ. Econ. Manage. 25 : 242-56

Dixon LS. 1995. The transactions costs generated by Superfund's liability approach. In Analyzing Superfund: Economics, Science and Law, eds. RL Revesz, RB Stewart, 171-85. Washington, D.C.: Resources for the Future

Ederington J, Levinson A, Minier J. 2005. Footloose and pollution-free. Rev. Econ. Stat. 87 : 92-9 
Eskeland GS, Harrison AE. 2003. Moving to greener pastures? Multinationals and the pollution haven hypothesis. J. Dev. Econ. 70 : 1-23

Evans MF, Liu L, Stafford SL. 2010. A facility-level analysis of the long-term consequences of environmental auditing among hazardous waste generators. SSRN eLibrary.

Forslund J, Johansson P, Samakovlis E, Vredin Johansson M. 2009. Can we buy time? Evaluation of the government's directed grant to remediation in Sweden. National Institute of Economic Research

Fredriksson PG, List JA, Millimet DL. 2003. Bureaucratic corruption, environmental policy and inbound US FDI: Theory and evidence. J. Public Econ. 87 : 1407-30

Fullerton D, Kinnaman TC. 1995. Garbage, recycling, and illicit burning or dumping. J. Environ. Econ. Manage. 29 : 78-91

Fullerton D, Wolverton A. 2005. The two-part instrument in a second-best world. J. Public Econ. 89 : 1961-75

Gamper-Rabindran S. 2006. Did the EPA's voluntary industrial toxics program reduce emissions? A GIS analysis of distributional impacts and by-media analysis of substitution. J. Environ. Econ. Manage. 52 : 391-410

Gamper-Rabindran S, Timmins C. 2010. Valuing the benefits of superfund site remediation: Three approaches to measuring localized externalities. Report to the EPA.

Gayer T. 2000. Neighborhood demographics and the distribution of hazardous waste risks: An instrumental variables estimation. J. Regul. Econ. 17 : 131-55

Gayer T, Hamilton JT, Viscusi WK. 2002. The market value of reducing cancer risk: Hedonic housing prices with changing information. South. Econ. J. $69: 266$

Gerking S. 2008. Decentralization and environmental decision making. In Fiscal Decentralization and Land Policies, ed. Y Hong and G Ingram, 169-89. Cambridge, Mass.: Lincoln Institute of Land Policy

Greenstone M. 2003. Estimating regulation-induced substitution: The effect of the Clean Air Act on water and ground pollution. Am. Econ. Rev. 93 : 442-8

Greenstone M, Gallagher J. 2008. Does hazardous waste matter? Evidence from the housing market and the superfund program. Q. J. Econ. 123 : 951-1003

Gupta S, Van Houtven G, Cropper M. 1996. Paying for permanence: An economic analysis of EPA's cleanup decisions at Superfund sites. Rand J. Econ. 27 : 563-82 
Hamilton JT, 2005. Environmental equity and the siting of hazardous waste facilities in OECD countries: Evidence and policies. In International Yearbook of Environmental and Resource Economics 2005/2006, eds. T Tietenberg and H Folmer, 97-156. Cheltenham, U.K. and Northampton, MA.: Edward Elgar

Hamilton JT. 1996. Going by the (informal) book: The EPA's use of informal rules in enforcing hazardous waste laws. In Reinventing Government and the Problem of Bureaucracy, ed. GD Libecap, 109-55. Greenwich, Conn. and London: JAI Press

Hamilton JT. 1993. Politics and social costs: Estimating the impact of collective action on hazardous waste facilities. Rand J. Econ. 24 : 101-25

Hamilton JT, Viscusi WK. 1999. Calculating risks? The spatial and political dimensions of hazardous waste policy. Cambridge and London: MIT Press

Harrington D, Deltas G, Khanna M. 2010. Does pollution prevention reduce toxic emissions? A dynamic panel data model. Presented at WCERE IV, Montreal

Ingberman DE. 1995. Siting noxious facilities: Are markets efficient? J. Environ. Econ. Manage. 29 : S20-33

Jackson TO. 2002. Environmental contamination and industrial real estate prices. J. Real Estate Res. 23 : 179-99

Jenkins RR, Kopits E, Simpson D. 2009. The evolution of solid and hazardous waste regulation in the United States. Rev. Environ. Econ. Policy. 3 : 104-20

Kellenberg D. 2010. Trading wastes. Presented at WCERE IV, Montreal

Khanna M, Brouhle K. 2008. Effectiveness of voluntary environmental initiatives. In Governing the Environment: Interdisciplinary Perspectives, eds. M Delmas, 0 Young, Cambridge, U.K.: Cambridge University Press

Khanna M, Damon LA. 1999. EPA's voluntary 33/50 program: Impact on toxic releases and economic performance of firms. J. Environ. Econ. Manage. 37 : 1-25

Kiel KA, McClain KT. 1995. House prices during siting decision stages: The case of an incinerator from rumor through operation. J. Environ. Econ. Manage. 28 : 241-55

Kiel KA, Williams M. 2007. The impact of Superfund sites on local property values: Are all sites the same? J. Urban Econ. 61 : 170-92

Kohlhase JE. 1991. The impact of toxic waste sites on housing values. J. Urban Econ. 30 : 1-26

Konisky DM. 2007. Regulatory competition and environmental enforcement: Is there a race to the bottom? Am. J. Polit. Sci. 51 : 853-72 
Kornhauser LA, Revesz RL. 1995. Evaluating the effects of alternative Superfund liability rules. In Analyzing Superfund: Economics, Science, and Law, eds. RL Revesz, RB Stewart, 115-44. Washington, D.C.: Resources for the Future

Kunreuther H, Kleindorfer P, Knez PJ, Yaksick R. 1987. A compensation mechanism for siting noxious facilities: Theory and experimental design. J. Environ. Econ. Manage. 14 : 371-83

Lambert T, Boerner C. 1997. Environmental inequity: Economic causes, economic solutions. Yale J. Regul. 14 : 195-234

Levinson A. 2003. Environmental regulatory competition: A status report and some new evidence. Natl. Tax J. 56 : 91-106

Levinson A. 1999a. NIMBY taxes matter: The case of state hazardous waste disposal taxes. J. Public Econ. 74 : 31-51

Levinson A. 1999b. State taxes and interstate hazardous waste shipments. Am. Econ. Rev. 89 : 666-77

Levinson A. 1996. Environmental regulations and manufacturers' location choices: Evidence from the census of manufactures. J. Public Econ. 62: 5-29

Levinson A, Taylor MS. 2008. Unmasking the pollution haven effect. Int. Econ. Rev. 49 : 22354

Maguire KB, Jenkins RR. 2009. State hazardous and solid waste taxes: Understanding their variability. Work. Pap., EPA National Center for Environmental Economics

McCluskey JJ, Rausser, GC. 2003. Stigmatized asset value: Is it temporary or long-term? Rev. Econ. Stat. 85 : 276-85

McGrath DT. 2000. Urban industrial land redevelopment and contamination risk. J. Urban Econ. $47: 414-42$

Mendelsohn R, Hellerstein D, Huguenin M, Unsworth R, Brazee R. 1992. Measuring hazardous waste damages with panel models. J. Environ. Econ. Manage. 22 : 259-71

Messer KD, Schulze WD, Hackett KF, Cameron TA, McClelland GH. 2006. Can stigma explain large property value losses? The psychology and economics of Superfund. Environ. Resour. Econ. 33 : 299-324

Millimet DL, List JA. 2004. The case of the missing pollution haven hypothesis. J. Regul. Econ. $26: 239-62$

Minehart D, Neeman Z. 2002. Effective siting of waste treatment facilities. J. Environ. Econ. Manage. $43: 303-24$ 
Noonan DS, Krupka DJ, Baden BM. 2007. Neighborhood dynamics and price effects of Superfund site clean-up. J. Reg. Sci. 47 : 665-92

Organization for Economic Cooperation and Development. 2010. OECD/EEA database on instruments used for environmental policy and natural resources management. http://www2.oecd.org/ecoinst/queries/index.htm

Pastor J, Manuel, Sadd J, Hipp J. 2001. Which came first? Toxic facilities, minority move-in, and environmental justice. J. Urban Aff. $23: 1$

Peretz JH, Bohm RA, Jasienczyk PD. 1997. Environmental policy and the reduction of hazardous waste. J. Policy Anal. Manag. 16 : 556-74

Polinsky AM, Shavell S. 1994. A note on optimal cleanup and liability after environmentally harmful discharges. Res. Law Ec. 16 : 17-24

Probst KN, Fullerton D, Litan RE, Portney PR. 1995. Footing the bill for Superfund cleanups: Who pays and how? Washington, D.C.: Brookings Institution Press. 176pp

Rausser GC, Simon LK, Zhao J. 1998. Information asymmetries, uncertainties, and cleanup delays at Superfund sites. J. Environ. Econ. Manage. 35 : 48-68

Russell CS. 1988. Economic incentives in the management of hazardous wastes. Colum. J. Envtl. L. $13: 257-74$

Sam A. 2010. Impact of government-sponsored pollution prevention practices on environmental compliance and enforcement: Evidence from a sample of US manufacturing facilities. J. Regul. Econ. 37 : 266-86

Schoenbaum M. 2002. Environmental contamination, brownfields policy, and economic redevelopment in an industrial area of Baltimore, Maryland. Land Econ. 78 : 60-71

Segerson K. 1994. Property transfers and environmental pollution: Incentive effects of alternative policies. Land Econ. 70 : 261-72

Segerson K. 1993. Liability transfers: An economic assessment of buyer and lender liability. J. Environ. Econ. Manage. 25 : S46-63

Shadbegian RJ, Wolverton A. 2010. Location decisions of U.S. polluting plants: Theory, empirical evidence, and consequences. Work. Pap., EPA National Center for Environmental Economics

Sigman H. 2010. Environmental liability and redevelopment of old industrial land. J. Law Econ. 53 : 289-306 
Sigman H. 2003. Taxing hazardous waste: The U.S. experience. Publ. Finance Manag. 3 : 12 33

Sigman H. 2001. The pace of progress at Superfund sites: Policy goals and interest group influence. J. Law Econ. 44 : 315-44

Sigman H. 2000. Hazardous waste and toxic substance policies. In Public Policies for Environmental Protection, eds. PR Portney, RN Stavins, 215-59. Washington, D.C: Resources for the Future

Sigman H. 1998a. Liability funding and Superfund clean-up remedies. J. Environ. Econ. Manage. 35 : 205-24

Sigman H. 1998b. Midnight dumping: Public policies and illegal disposal of used oil. Rand J. Econ. 29 : 157-78

Sigman H. 1996a. Cross-media pollution: Responses to restrictions on chlorinated solvent releases. Land Econ. $72: 298-312$

Sigman H.1996b. The effects of hazardous waste taxes on waste generation and disposal. J. Environ. Econ. Manage. 30 : 199-217

Sigman HA. 1995. A comparison of public policies for lead recycling. Rand J. Econ. 26 : 45278

Sigman H, Traub LG. 2007. Voluntary decentralization in environmental policy: 'Cooperative federalism' as a strategic interaction. Work. Pap., NBER.

Stafford SL. 2007a. Can consumers enforce environmental regulations? The role of the market in hazardous waste compliance. J. Regul. Econ. 31 : 83-107

Stafford SL. 2007b. Should you turn yourself in? The consequences of environmental selfpolicing. J. Policy Anal. Mgmt. $26:$ 305-26

Stafford SL. 2006. Rational or confused polluters? Evidence from hazardous waste compliance. BE J. Econ. Anal. Poli. (Contributions) 5(1) : Art 1

Stafford SL. 2003. Assessing the effectiveness of state regulation and enforcement of hazardous waste. J. Regul. Econ. 23 : 27-41

Stafford SL. 2002. The effect of punishment on firm compliance with hazardous waste regulations. J. Environ. Econ. Manage. $44:$ 290-308

Stafford SL. 2000. The impact of environmental regulations on the location of firms in the hazardous waste management industry. Land Econ. 76 : 569 
Tietenberg TH. 1989. Indivisible toxic torts: The economics of joint and several liability. Land Econ. 65 : 305-19

U.S. EPA. 2009. Challenges in applying property value studies to assess the benefits of the superfund program, Washington, D.C.: Office of Superfund Remediation and Technology Innovation.

U.S. EPA. 2008. The national biennial RCRA hazardous waste report (based on 2007 data). Rep. EPA530-R-08-012, Office of Solid Waste and Emergency Response, Washington, D.C.

United Church of Christ (UCC), Commission for Racial Justice. 1987. Toxic wastes and race in the United States: A national report on the racial and socioeconomic characteristics of communities with hazardous waste sites, New York: United Church of Christ.

Vidovic M, Khanna N. 2007. Can voluntary pollution prevention programs fulfill their promises? Further evidence from the EPA's 33/50 program. J. Environ. Econ. Manage. 53 : $180-95$

Viscusi WK, Hamilton JT. 1999. Are risk regulators rational? Evidence from hazardous waste cleanup decisions. Am. Econ. Rev. 89 : 1010-27

Wernstedt K, Meyer PB, Alberini A. 2006. Attracting private investment to contaminated properties: The value of public interventions. J. Policy Anal. Manag. 25 : 347-69

Wolverton A. 2009. Effects of socio-economic and input-related factors on polluting plants' location decisions. BE J. Econ. Anal. Poli. (Advances) 9 (1) 